\title{
Effects of Organic Nutrient Sources and NPS Fertilizer on the Agronomic and Economic Performance of Haricot Bean (Phaseolus vulgaris L.) in Southern Ethiopia
}

\author{
Ermias Elka and Fanuel Laekemariam \\ College of Agriculture, Wolaita Sodo University, P.O. Box 138, Wolaita Sodo, Ethiopia \\ Correspondence should be addressed to Fanuel Laekemariam; laeke2005@yahoo.com
}

Received 13 April 2020; Revised 27 July 2020; Accepted 30 July 2020; Published 17 August 2020

Academic Editor: Claudio Cocozza

Copyright (c) 2020 Ermias Elka and Fanuel Laekemariam. This is an open access article distributed under the Creative Commons Attribution License, which permits unrestricted use, distribution, and reproduction in any medium, provided the original work is properly cited.

\begin{abstract}
Despite the fact that mineral fertilizers are widely considered as a major option for addressing the crisis of nutrient depletion, their use among smallholder farmers is not adequate due to an escalating cost. Alternatively, nutrient-rich organic sources that are easily available to farmers are not widely promoted. Thus, this study was carried out in the research field of Wolaita Sodo University, Southern Ethiopia, to evaluate the effects of locally available organic nutrient sources and nitrogen (N) phosphorus (P) sulfur $(\mathrm{S})$ fertilizer $\left(19 \mathrm{~N}-46 \mathrm{P}_{2} \mathrm{O}_{5}-7 \mathrm{~S}\right)$ on the productivity and economic performance of common bean. The organic materials used were Croton (Croton macrostachyus) and Erythrina (Erythrina brucei) at $2: 1$ ratio, respectively. The experiment was laid out in a randomized complete block design with three replications. Treatments for organic fertilizer (OF) were $0,2.5$, and $5 \mathrm{t} \cdot \mathrm{ha}{ }^{-1}$ and for NPS fertilizer were $0,50,100$, and $150 \mathrm{~kg} \cdot \mathrm{ha}^{-1}$. Chemical composition analysis of organic materials showed high nutrient content where the amount varied from $4.7 \%-5.2 \% \mathrm{~N}, 11.07-18.6 \mathrm{mg} / \mathrm{kg} \mathrm{P}$, and $2.12 \%-3.07 \% \mathrm{~K}$. Results on agronomic parameters revealed that the leaf area index, grain weight, number of pods per plant, dry matter per plant, and grain yield of haricot bean were significantly affected by both main and combined effects of NPS and OF fertilizers. The grain yield under integrated application of $150 \mathrm{~kg} \mathrm{NPS} / \mathrm{ha}$ and $2.5 \mathrm{t} \cdot \mathrm{OF} / \mathrm{ha}(4.16 \mathrm{t} / \mathrm{ha})$ was significantly higher than that obtained from unfertilized crop (1.01 t/ha) by $312 \%$. Additionally, it resulted in 34\%, 31\%, and 79\% yield increment over the blanket dose $\left(100 \mathrm{~kg} \cdot \mathrm{NPS} \cdot \mathrm{ha} \mathrm{H}^{-1}\right), 2.5 \mathrm{t} / \mathrm{ha}$ and $5 \mathrm{t} / \mathrm{ha}$, respectively. It was also noted that resource-poor farmers, compared to unfertilized crop, can get grain yield superior by $130 \%$ and $214 \%$ using sole OF at 2.5 and $5 \mathrm{t} \cdot \mathrm{ha}^{-1}$, respectively. Furthermore, the highest economic benefit $(27,179.5 \mathrm{EtB})$ was recorded from $150 \mathrm{~kg}$ NPS $/ \mathrm{ha}+2.5 \mathrm{t} \cdot \mathrm{OF} / \mathrm{ha}$. The finding suggested that locally available organic materials of plant origin alone/integrated with NPS fertilizer are helpful for increased yield of haricot bean.
\end{abstract}

\section{Introduction}

Agriculture, a soil-based industry, is supporting the livelihood for over $80 \%$ of the Ethiopian population that is estimated 114 million in 2020 [1]. In order to feed the growing population in the country, the need to produce more per unit area is increasing ever so rapidly. Meanwhile, an increase in productivity is likely attained through adequate and balanced supply of nutrients. Yet, declining soil fertility is a serious problem to crop production and food security that has long gone unsolved.
Emerging research outcomes from various parts of Ethiopia demonstrated alarmingly low soil organic matter (SOM) and deficiencies of essential nutrients such as nitrogen $(\mathrm{N})$, phosphorus $(\mathrm{P})$, potassium $(\mathrm{K})$, sulfur $(\mathrm{S})$, boron (B), and copper $(\mathrm{Cu})$ as the main causes of crop yield decline and nonsustainable agricultural production [2-5]. The problems are attributed to continuous cropping of the same land year after year, inadequate replenishment of the lost nutrients, complete residue removal from the field, and soil erosion [6]. In order to curb the soil nutrient depletion, fertilizers, namely, 
organic, inorganic, or their integration are used as the source of essential plant nutrients.

Mineral fertilizers are widely considered as a major option for addressing the crisis of nutrient depletion and sustaining food production. In Ethiopia, application of inorganic fertilizer containing $\mathrm{N}$ and $\mathrm{P}$ in the form of urea $(46 \mathrm{~N}-0-0)$ and diammonium phosphate (DAP) $(18 \mathrm{~N}-$ $46 \mathrm{P}_{2} \mathrm{O}_{5}$ ) has long been started some 50 years ago after realizing that both nutrients are a widespread problem. However, crop yield gain from both fertilizers is gradually declining over time despite steady increases in fertilizer consumption in the country $[7,8]$. Insufficient and longterm application of the soil using $\mathrm{N}$ and $\mathrm{P}$ fertilizers has aggravated the depletion of macro- and micronutrients from inherent nutrient stacks [8-10] and resulted in variable yield even within the same field receiving the same input and management [11]. As a way out strategy, the government of Ethiopia following the EthioSIS (Ethiopian Soil Information System) recommendation has introduced new compound (e.g., NPS (19N-46 $\left.\mathrm{P}_{2} \mathrm{O}_{5}-7 \mathrm{~S}\right)$ ) and blended fertilizers containing micronutrients [2, 3]. Yet, subsistence farmers reasoning the high pricing of fertilizers apply far below the blanket rate [9]. Apart from this, mineral fertilizers are also blamed for the harmful effects on soil microorganisms and the environment.

The use of organic nutrient sources derived either from livestock or plants has been receiving worldwide support as they are the store house and source of several essential plant nutrients $[12,13]$. They are also used to correct the marginal deficiencies of secondary and micronutrients which are, in most cases, not addressed by mineral fertilizers. Furthermore, organic fertilizing sources influence soil physical properties as well as soil microbial activity [14], and subsequently improve crop productivity [15]. Despite the positive impacts, locally available materials of plant origin, particularly biomass transfer from agroforestry leaves, which are easily available to farmers are not being fully utilized and not widely appreciated as resources. Moreover, the large amount of organic material required to meet crop nutrient demand makes it challenging for wider use $[15,16]$.

According to Alhrout et al. [17], neither organic nor mineral fertilizers can stand on their own to solve soil fertility depletion problems. Thus, integrated use of organic and mineral fertilizers is suggested as it overcomes the limitations that both fertilizers are encountering. Particularly, under nutrient limiting soils, the practice stimulated the activity of microorganisms, enhanced decomposition of organic residues and release of essential nutrients, and subsequently, improved grain yield [13, 18-22]. In addition, integrated nutrient management has helped to reduce the cost of mineral fertilizer up to 50\% [23] or more [15]. However, information on the effects of locally available organic materials of plant origin and the recently introduced NPS (19N-46 $\left.\mathrm{P}_{2} \mathrm{O}_{5}-7 \mathrm{~S}\right)$ fertilizer under nutrient poor soils of Southern Ethiopia has been lacking. Thus, the aim of this experiment was to evaluate the effects of organic nutrient sources, mineral fertilizer, and their combination on the agronomic and economic performance of haricot bean (Phaseolus vulgaris L.).

\section{Methodology}

2.1. Location. The study was carried out in 2017 at the Wolaita Sodo University (WSU) research and practical farm in Sodo Zuria district, Southern Ethiopia. Geographically, it is located in $06^{\circ} 50^{\prime} 00^{\prime \prime} \mathrm{N}$ latitude and $37^{\circ} 45^{\prime} 07^{\prime \prime} \mathrm{E}$ longitude with an altitude of $1882 \mathrm{~m}$ above the mean sea level. The annual average rainfall was $1212 \mathrm{~mm}$ and characterized by having a bimodal rainfall pattern that forms two cropping seasons, namely, Belg (February-May) and meher (JuneSeptember). Farmers cultivate different crops during the two seasons.

Nitisol is the dominant soil type which occurs in the experimental location and district. The site has clay textural class. In terms of chemical properties, the experimental site had slightly acidic reaction $(\mathrm{pH}=5.9)$ with low content of organic carbon (OC) (0.17\%), total nitrogen (0.01), and available $\mathrm{P}(5.4 \mathrm{mg} / \mathrm{kg})$ [24]. The low OC could be explained by the lack of addition of organic resources. Major annual crops growing in the area include haricot bean (Phaseolus vulgaris $\mathrm{L}$.), wheat (Triticum aestivum L.), and maize (Zea mays $\mathrm{L}$ ).

2.2. Treatments, Research Design, and the Experimental Procedure. A factorial experiment consisting of three levels of organic fertilizer $\left(0,2.5\right.$ and $\left.5 \mathrm{t} \cdot \mathrm{ha}^{-1}\right)$ and four levels of NPS fertilizer $\left(0,50,100\right.$ and $\left.150 \mathrm{~kg} \cdot \mathrm{ha}^{-1}\right)$ was arranged in a Randomized Complete Block Design (RCBD) with three replications. Nutrients from organic sources were obtained from two agroforestry tree leaves, namely, Croton (Croton macrostachyus) and Erythrina (Erythrina brucei). These trees are growing in crops fields and/or farm boundaries; and farmers prune the tree branches and mulch the green leaves to enhance soil fertility. Each experimental unit had $2.40 \mathrm{~m}$ length $\times 1 \mathrm{~m}$ width $\left(2.4 \mathrm{~m}^{2}\right)$ in which the length was divided into six rows at $40 \mathrm{~cm}$ intervals. Each row was opened at $20 \mathrm{~cm}$ depth (i.e., average plough layer), and the whole doses of organic and inorganic fertilizers as per the treatment were applied into the soil two weeks prior to sowing of the test crop variety Nasir.

Two seeds per hill were planted in rows $40 \mathrm{~cm}$ apart and, with $10 \mathrm{~cm}$ between seeds. A distance of $0.5 \mathrm{~m} \times 1 \mathrm{~m}$ was left between plots and blocks, respectively. Thinning was performed after full emergence of the crop by leaving one seedling per hill. Each plot had six rows and a total of 60 plants per plot. Weeding and other necessary agronomic management practices were carried out properly. These procedures were repeated on each of crop-growing seasons.

2.3. Chemical Composition of Organic Residues. Organic materials collected from the tree leaves were chopped, dried in shade, and then, oven dried at $70^{\circ} \mathrm{C}$ until constant weight. The leave litters were ground and used for characterization of chemical composition. The chemical composition, namely, $\mathrm{N}, \mathrm{P}, \mathrm{K}$, and $\mathrm{OC}$, and $\mathrm{C}: \mathrm{N}$ contents of organic materials were determined according to the work of Sahlemedhin and Taye [25]. The samples were analyzed at the JIJE Analytical Testing Service Laboratory, 
Addis Ababa, Ethiopia. This procedure was completed prior to planting of the crop.

2.4. Crop Data Collection. Data on the plant height, leaf area index (LAI), and dry matter per plant were recorded from five randomly selected plants of internal rows. The plant height was measured from the base of the plant to the apical bud of plant and expressed in centimeters. The leaf area index (LAI) was calculated as the ratio of total leaf area to ground area occupied by the plant using a pictorial method [26]. Dry matter per plant was measured after oven drying of the sample plants to constant weight at $70^{\circ} \mathrm{C}$ for 48 hours.

Yield components, namely, numbers of branches per plant, numbers of pods per plant, and numbers of seeds per pods, and 1000 seeds weights were also recorded from randomly selected five plants at two central rows of the plot. Grain yield was collected on a plot bases and after 10\% moisture adjustment, it was converted to ton/ha.

2.5. Economic Analysis. The partial budget analysis was carried out using the methodology described in CIMMYT [27]. Grain yield data was used for the analysis. The price of $1 \mathrm{~kg}$ of haricot bean grain at local market near the experimental site was taken as 8.0 Ethiopian Birr (ETB). The price of NPS fertilizer was $15.15 \mathrm{~kg}^{-1}$ ETB. The average labor cost incurred for incorporating $1.0 \mathrm{t} \cdot \mathrm{ha}^{-1}$ of E. brucei biomass was 200 ETB. Then, the total variable cost (TVC) was calculated as the sum of all costs that are variable or specific to a treatment against an unfertilized plot. The gross benefit (GB) was calculated as average adjusted grain yield $\left(\mathrm{kg} \cdot \mathrm{ha}^{-1}\right) \times$ grain price. Adjusted Yield (AY) refers to $90 \%$ of the total grain yield that was adjusted downward by a certain percentage to reflect the difference between the experimental yield and the yield farmers could expect from the same treatment. Net benefit was calculated by subtracting TVC from the GB. The marginal rate of return (MRR) was calculated as the ratio of differences between net benefits of successive treatments to the difference between TVC of successive treatments. The minimum acceptable MRR is $100 \%$.

2.6. Statistical Analysis. All data obtained from experiments were subjected to analysis of variance (ANOVA) using SAS [28]. When effects were significant, means were compared using least significant difference (LSD) at a probability level of 5\%. Pearson's correlation and simple regressiosn analysis were performed to evaluate relationships among selected parameters.

\section{Result and Discussion}

3.1. Chemical Composition of Organic Nutrient Sources. The chemical composition of Croton (Croton macrostachyus) and Erythrina (Erythrina brucei) used for the study is presented in Table 1. The organic carbon content of Croton and Erythrina ranged from 50.8 to $51.8 \%$, respectively. Croton has higher N (5.2\%) than $4.7 \%$ on Erythrina. The N
TABLE 1: Chemical characteristics of organic nutrient sources.

\begin{tabular}{lccccc}
\hline Leave litters & OC & $\mathrm{N}$ & $\mathrm{P}$ & $\mathrm{K}$ & $\mathrm{C}: \mathrm{N}$ \\
& $\%$ & $\%$ & $\mathrm{mg} / \mathrm{kg}$ & $\%$ & - \\
\hline Croton & 50.83 & 5.2 & 11.07 & 3.07 & 10 \\
Erythrina & 51.83 & 4.7 & 18.59 & 2.12 & 11 \\
\hline
\end{tabular}

content of both nutrient sources was above $2.5 \%$, which is the threshold value indicating the quality of organic material and implying that, in short term, it would result in $\mathrm{N}$ mineralization in soil [29]. Phosphorus contents $(\mathrm{mg} / \mathrm{kg})$ were 11.07 in Croton and 18.6 in Erythrina. The potassium $(\mathrm{K})$ content also varied from $2.12 \%$ (Erythrina) to $3.07 \%$ (Croton). Furthermore, the $\mathrm{C}: \mathrm{N}$ ratio also varied between 10 and 11 which denotes higher decomposition probably due to the presence of less resistant structures and organic compounds. This would result in a faster rate of decomposition and release of essential nutrients to the crop. In agreement, Gindaba et al. [30] on green leaves of Croton and Wassie [15] on Erythrina found C: $\mathrm{N}$ ratio less than 20 and higher $\mathrm{N}$ content (4.83\%), respectively. Overall, the chemical characteristics of organic nutrient sources were found to be high and encouraging to use as soil amendment.

\subsection{Growth and Yield of Common Bean}

3.2.1. Plant Height. The plant height of haricot bean plants was significantly $(p<0.001)$ increased with successive increase of NPS and organic fertilizer (OF) but not by their interaction (Table 2). Application of $150 \mathrm{~kg} \cdot \mathrm{NPS} / \mathrm{ha}$ had resulted in $48 \%$ taller plants compared to nonfertilized plants. On the other hand, application of organic fertilizer at 5 ton/ha recorded $23 \%$ taller plants over the control. However, it was at par with 2.5 ton/ha. The plant height exhibited progressive increment with increasing rates of either NPS or OF fertilizer. The taller plants at higher doses of both fertilizer types can be associated with the complementary effects of $\mathrm{N}, \mathrm{P}$, and $\mathrm{S}$ and other nutrients released from organic matter decomposition. In line with this, the maximum plant height at increasing rate of NPS [31] and NPKSB [32] on haricot bean was reported.

3.2.2. Leaf Area Index. The leaf area index (LAI) of haricot bean was significantly influenced by the combined effects of NPS and OF application (Table 3). The maximum (4.49) and minimum (1.35) LAI were attained from $150 \mathrm{~kg} \cdot \mathrm{NPS} / \mathrm{ha}+5$ ton/ha and the nonfertilized plot, respectively (Table 3 ). The treatment with a maximum LAI has resulted in $233 \%$ more LAI compared to unfertilized treatment. Integrating NPS along with other nutrients provided by $\mathrm{OF}$ at increasing rate had shown an increase in the LAI which was attributed to supplying of balanced nutrients (Figure 1). $\mathrm{N}$ resulted in more foliage and promoted photosynthetic action, $\mathrm{P}$ has a role in the synthesis of cellulose and hemicelluloses, which is leading to the expansion of individual leaves, and $\mathrm{K}$ and $\mathrm{S}$ encourage vegetative growth of common bean $[26,33]$. 
TABle 2: Plant height, branches per plant, and seeds per pods affected by NPS and organic fertilizer.

\begin{tabular}{lccc}
\hline & $\begin{array}{c}\text { Plant height } \\
(\mathrm{cm})\end{array}$ & $\begin{array}{c}\text { Branch plant }^{-1} \\
(\text { No. })\end{array}$ & $\begin{array}{c}\text { Seed pod }^{-1} \\
(\text { No. })\end{array}$ \\
\hline NPS (kg/ha) & & & \\
0 & $57.972 \mathrm{~d}$ & $3.4444 \mathrm{~d}$ & $2.8622 \mathrm{c}$ \\
50 & $69.906 \mathrm{c}$ & $4.4778 \mathrm{c}$ & $4.0889 \mathrm{~b}$ \\
100 & $77.339 \mathrm{~b}$ & $4.9889 \mathrm{~b}$ & $4.5478 \mathrm{a}$ \\
150 & $85.856 \mathrm{a}$ & $5.6778 \mathrm{a}$ & $4.9033 \mathrm{a}$ \\
$\mathrm{LSD}$ & $\mathbf{6 . 9 8 5 9}$ & $\mathbf{0 . 3 8 9 0}$ & $\mathbf{0 . 4 1 9 1}$ \\
OF (t/ha) & & & \\
0 & $64.279 \mathrm{~b}$ & $4.0167 \mathrm{~b}$ & $3.6075 \mathrm{c}$ \\
2.5 & $75.050 \mathrm{a}$ & $4.8250 \mathrm{a}$ & $4.1192 \mathrm{~b}$ \\
5 & $78.975 \mathrm{a}$ & $5.100 \mathrm{a}$ & $4.5750 \mathrm{a}$ \\
$\mathrm{LSD}$ & $\mathbf{6 . 0 5 0 0}$ & $\mathbf{0 . 3 3 6 9}$ & $\mathbf{0 . 3 6 2 9}$ \\
$\mathrm{CV}(\%)$ & $\mathbf{9 . 8 2}$ & $\mathbf{8 . 5 6}$ & $\mathbf{1 0 . 4 5}$ \\
\hline
\end{tabular}

Nutrient sources of organic and inorganic when combined create a synergistic effect to increase the leaf area and LAI. In line to this, Zahida et al. [21] also reported that integrated fertilizer application results in a significantly higher LAI of common bean over sole and nonfertilized plots. Similarly, Nasim et al. [34] on maize also reported a maximum LAI in plot fertilized with a combination of poultry manure and $\mathrm{N}$ fertilizer.

In our study, a faster daily decay rate $(k)$ and decomposition were recorded when organic nutrient sources are treated with $150 \mathrm{~kg} \cdot \mathrm{NPS} / \mathrm{ha}$. This implies that mineralization and release of nutrients to the crop were started since the early crop growth period. The correlation analysis further indicated that the LAI has a significant $(p<0.01)$ relationship with $k(r=0.63)$, NPS $(r=0.73)$, and OF $(r=0.38)$. This could contribute to increased synchrony between nutrient demand and supply that resulted to more number of leaves per plant and higher LAI of plants.

3.2.3. Yield Attributes. The number of branches per plant and seeds per pod were significantly $(p<0.01)$ affected by the main effects of NPS and OF application (Table 2), whereas their interaction affected pods per plant and thousand seed weight (Table 3). NPS at $150 \mathrm{~kg} / \mathrm{ha}$ and OF at $5 \mathrm{t} /$ ha have resulted in $67 \%$ and $28 \%$ more branches per plant than by unfertilized treatment. Moreover, the earlier NPS and OF treatments in their order have also resulted in $69 \%$ and $28 \%$ higher seeds per pod than control. Generally, branches per plant and seeds per pod of haricot bean have shown an increasing trend with an increasing rate of either fertilizer sources.

Integrated application of $150 \mathrm{~kg}$ NPS/ha $+2.5 \mathrm{t} / \mathrm{ha}$ OF significantly enhanced the pod number per plant by $227 \%$ over unfertilized plots (Figure 2). The advantage in yield attributes was probably caused by greater availability and uptake of macro- and micronutrients that might have resulted in higher photosynthesis, tissue differentiation, and assimilation of translocation and, in turn, leading to better vegetative growth (e.g., LAI and higher total dry matter production) and yield attributes (branches and pods/plant). The Pearson correlation matrix (Table 4) also indicated that the number of pods per plant was significantly associated with the NPS $(r=0.73)$, OF $(r=0.38)$, LAI $(r=0.86)$, dry matter production $(r=0.8)$, and number of branches per plant $(r=0.744)$.

The results regarding yield attributes are in accordance with the findings of Zahida et al. [21] who reported the highest branches/plant in plots treated with NPK and poultry manure or farm yard manure. Furthermore, similar results on chickpea were also reported by Sohu et al. [19]. According to Ahmad and Abdin [35], applications of $\mathrm{N}$ and $\mathrm{S}$ fertilizers enhance the net photosynthetic rate in crop plants, which in turn, increases dry matter, yield attributes, and grain yield. The effect would become better when organic fertilizer is mixed together. This is due to the fact that organic fertilizer would have provided the micronutrients in addition to macronutrients $[12,13]$.

3.2.4. Biomass per Plant and Grain Yield. Interactive effects of NPS and OF significantly $(p<0.05)$ influenced the biomass yield of haricot bean (Table 3). Application of $150 \mathrm{~kg}$ NPS/ha and $5 \mathrm{t} / \mathrm{ha}$ recorded the highest dry biomass per plant $(45.2 \mathrm{~g})$ compared to the minimum $(12.2 \mathrm{~g})$ from unfertilized crop. Biomass production has shown an increasing trend with an increasing rate of NPS + OF fertilizers. The better performance under integrated nutrient application was closely associated with improvement in the LAI and yield attributes. This is supported by a significant and positive association with the NPS $(r=0.64)$, OF $(r=0.53)$, LAI $(r=0.78)$, plant height $(r=0.84)$, pods per plant $(r=0.8)$, and seeds per pod $(r=0.86)$ (Table 4$)$. For instance, the higher LAI of plants enabled plants to intercept more of the available radiation for the production of assimilates. This was, in turn, dependent upon nutrient availability. Ashenafi [26] had also reported increased biomass yield of common bean cultivars with an increase in the rate of NPS. The author associated to enhanced availability and uptake of $\mathrm{N}, \mathrm{P}$, and $\mathrm{S}$ nutrients that significantly improved the plant height, number of branches, and number of pods per plant that contributed to higher above ground dry biomass yield.

Data regarding grain yield indicated that application of $150 \mathrm{~kg} \mathrm{NPS} / \mathrm{ha}$ and $2.5 \mathrm{t} . \mathrm{OF} / \mathrm{ha}$ significantly resulted the highest grain yield $(4.16 \mathrm{t} / \mathrm{ha})$ which was a $312 \%$ increase over unfertilized crop (1.01 t/ha) (Figure 3, Table 3). In addition, it also recorded $31 \%, 79 \%$, and $34 \%$ yield increment over sole application of organic fertilizer at 2.5 $\mathrm{t} / \mathrm{ha}, 5 \mathrm{t} / \mathrm{ha}$, and $100 \mathrm{~kg}$.NPS/ha (i.e., blanket dose), respectively. Abdou et al. [36] reported that combined application of organic and inorganic nutrient sources resulted in synergistic effects and improved synchronization of nutrient release and uptake by plants leading to higher yields. In addition, mixing the organic nutrient sources with mineral fertilizer enhanced decomposition and mineralization $[12,13]$ and consequently improved nutrient release and uptake leading to higher yield $[12,22]$. In the present study, enhanced decomposition at an increasing rate of NPS, and a significant $(p<0.01)$ 


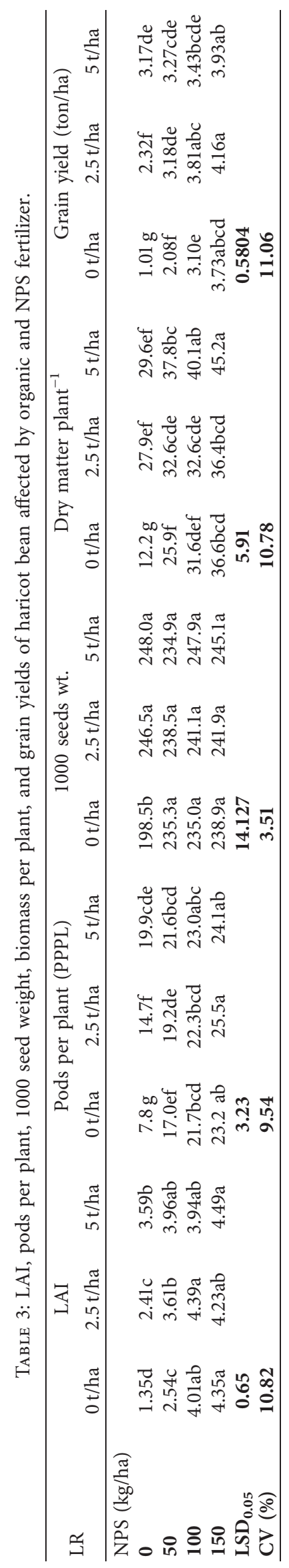




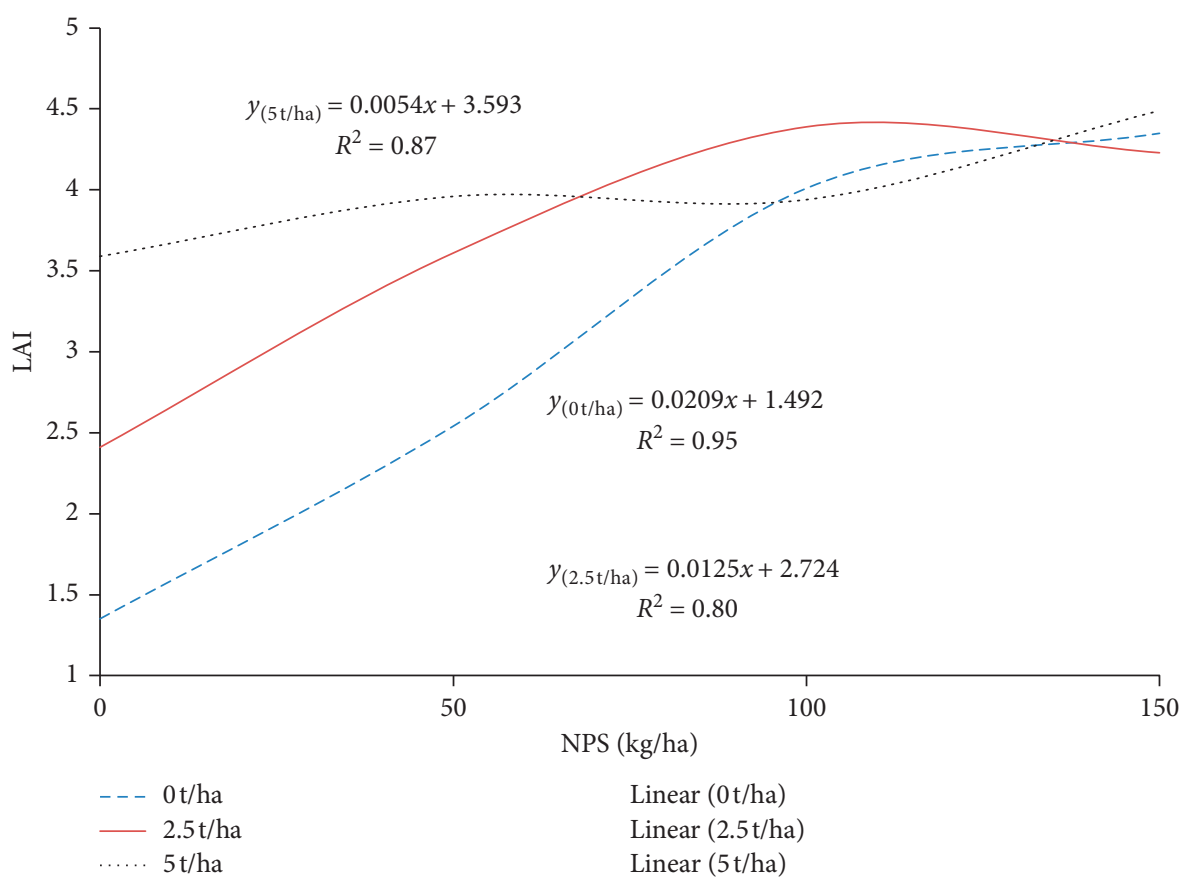

FIGURE 1: Leaf area index of haricot bean as affected by interaction effects of NPS and organic fertilizer.

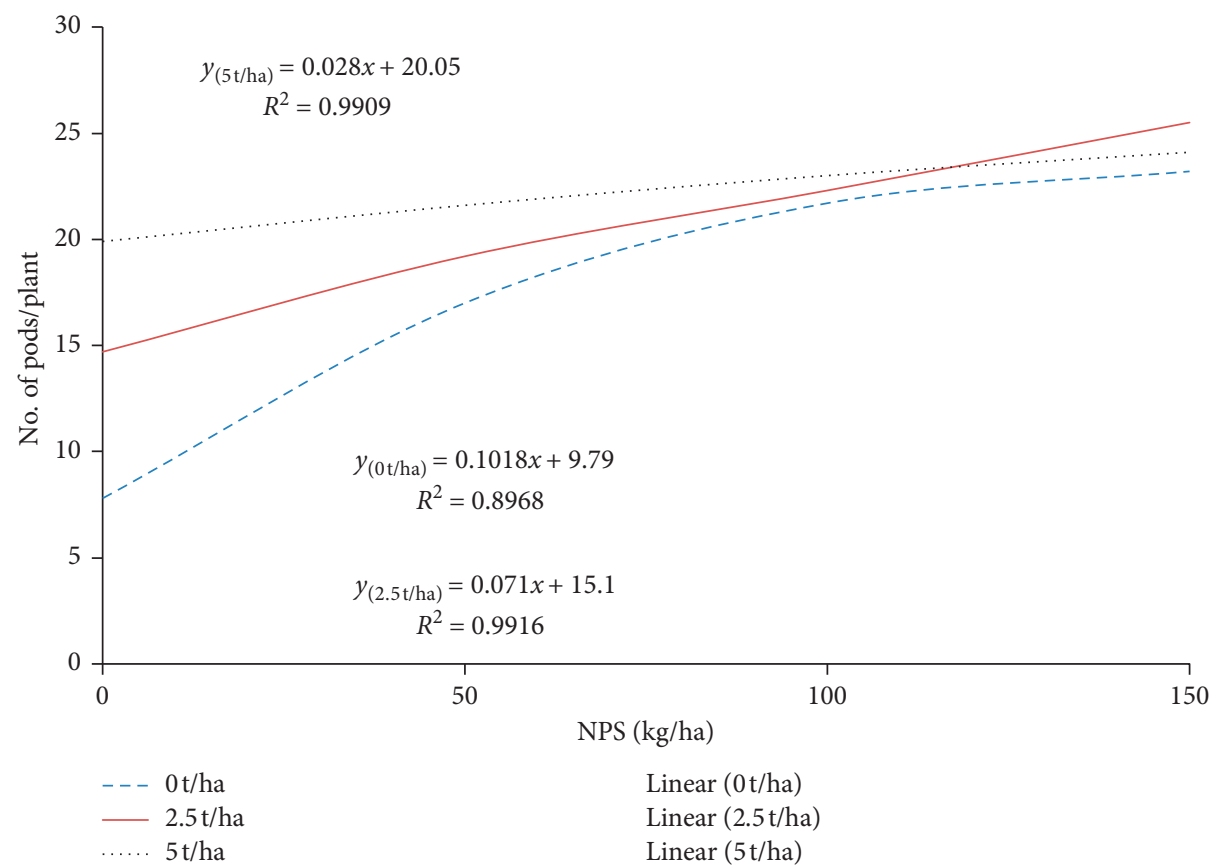

FIGURE 2: Number of pods/plant of haricot bean as affected by interaction effects of NPS and organic fertilizer.

relationship between grain yield and daily decay rate $(k)$ $(r=0.67)$ were recorded. All these processes have been a good reason for vigorous vegetative growth, higher dry matter accumulation, increased yield attributes, and the resultant effect on grain yield of bean. Earlier studies have also reported that combined application of mineral and organic fertilizer resulted in higher grain yield $[13,22,37,38]$.
3.3. Economic Analyses. The result revealed that the application of $150 \mathrm{~kg} \cdot \mathrm{NPS} / \mathrm{ha}+2.5 \mathrm{t} \cdot \mathrm{OF} / \mathrm{ha}$ recorded the highest net benefit (27179.5 birr) with acceptable MRR (>100\%) (Figure 4, Table 5). It was followed by net benefit (25417.0 ETB) at $100 \mathrm{~kg}$ $\mathrm{NPS} /$ ha and $2.5 \mathrm{t} \cdot \mathrm{OF} / \mathrm{ha}$. The finding also demonstrated that resource-poor farmers can get reasonable benefit ranging from 16204.0 to 21824.0 ETB by sole application of organic nutrients at $2.5 \mathrm{t} \cdot \mathrm{OF} / \mathrm{ha}$ and $5 \mathrm{t} \cdot \mathrm{OF} / \mathrm{ha}$, respectively. 
TABLE 4: Pearson correlation matrix of applied fertilizers and agronomic parameters.

\begin{tabular}{|c|c|c|c|c|c|c|c|c|c|c|}
\hline & NPS & OF & LA & LAI & PHT & BPL & PODPT & SEDPOD & TSW & BIOMP \\
\hline LA & $0.768^{* * *}$ & $0.434^{* *}$ & & & & & & & & \\
\hline LAI & $0.730^{* * *}$ & $0.384^{*}$ & $0.862^{* * *}$ & & & & & & & \\
\hline PHT & $0.735^{* * *}$ & $0.433^{* *}$ & $0.845^{* * *}$ & $0.834^{* * *}$ & & & & & & \\
\hline BPL & $0.753^{* * *}$ & $0.412^{*}$ & $0.835^{* * *}$ & $0.803^{* * *}$ & $0.843^{* * *}$ & & & & & \\
\hline PODPT & $0.727^{* * *}$ & $0.375^{*}$ & $0.801^{* * *}$ & $0.863^{* * *}$ & $0.834^{* * *}$ & $0.744^{* * *}$ & & & & \\
\hline SEDPOD & $0.779^{* * *}$ & $0.418^{*}$ & $0.836^{* * *}$ & $0.808^{* * *}$ & $0.810^{* * *}$ & $0.850^{* * *}$ & $0.758^{* * *}$ & & & \\
\hline TSW & $0.274^{\mathrm{ns}}$ & $0.448^{* *}$ & $0.556^{* * *}$ & $0.565^{* * *}$ & $0.564^{* * *}$ & $0.442^{* *}$ & $0.695^{* * *}$ & $0.382^{*}$ & & \\
\hline BIOMP & $0.639^{* * *}$ & $0.528^{* * *}$ & $0.804^{* * *}$ & $0.777^{* * *}$ & $0.836^{* * *}$ & $0.836^{* * *}$ & $0.800^{* * *}$ & $0.861^{* * *}$ & $0.584^{* * *}$ & \\
\hline GY & $0.696^{* * *}$ & $0.414^{*}$ & $0.834^{* * *}$ & $0.862^{* * *}$ & $0.765^{* * *}$ & $0.705^{* * *}$ & $0.873^{* * *}$ & $0.642^{* * *}$ & $0.638^{* * *}$ & $0.626^{* * *}$ \\
\hline
\end{tabular}

${ }^{*, * * * * * *}$ and ${ }^{\mathrm{ns}}$ refer to $p<0.05,0.01,0.001$, and not significant, respectively. $\mathrm{LA}=$ leaf area, $\mathrm{LAI}=$ leaf area index, $\mathrm{PHT}=$ plant height, $\mathrm{BPL}=$ no of branches per plant, $\mathrm{PODPT}=$ no of pods per plant, $\mathrm{SEDPOD}=$ no of seeds per pod, $\mathrm{TSW}=$ thousand seed weight, $\mathrm{BIOMP}=$ biomass per plant, $\mathrm{GY}=$ grain yield .

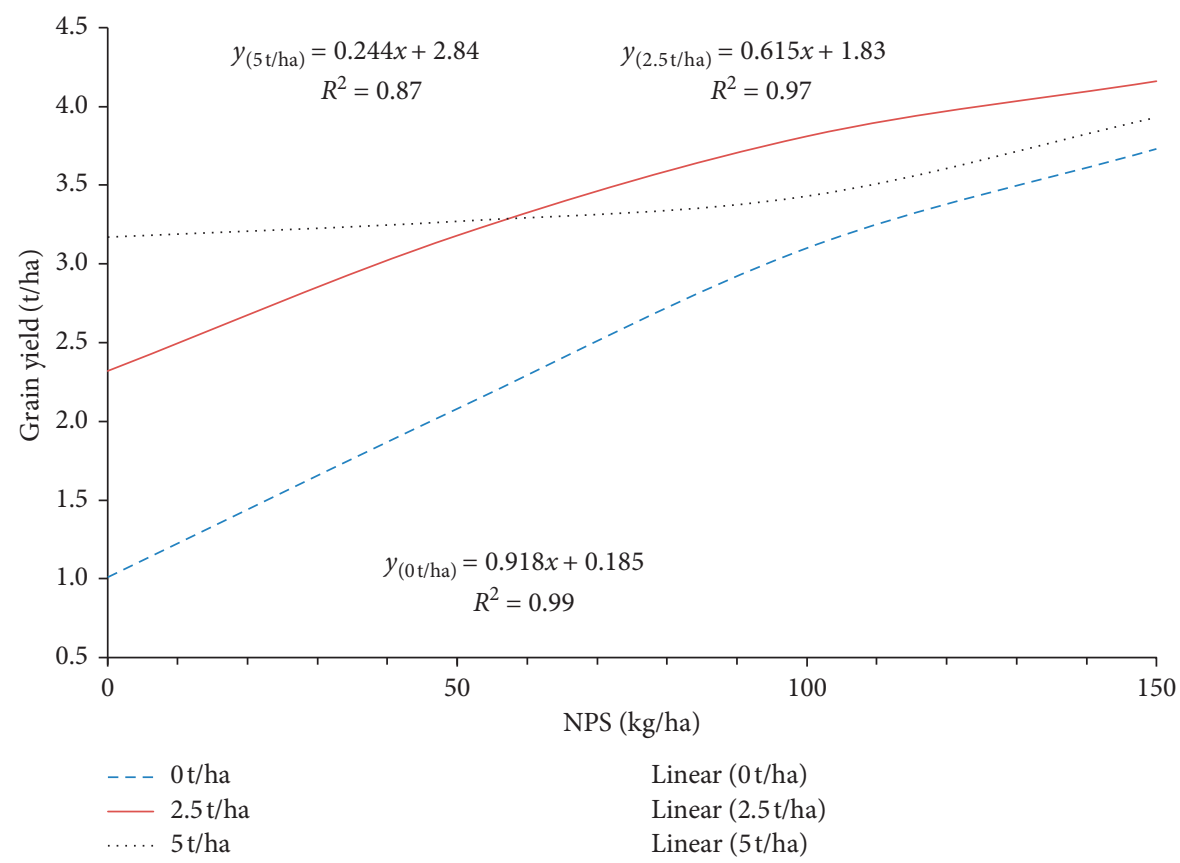

FIGURE 3: Grain yield of haricot bean as affected by interaction effects of NPS and organic fertilizer.

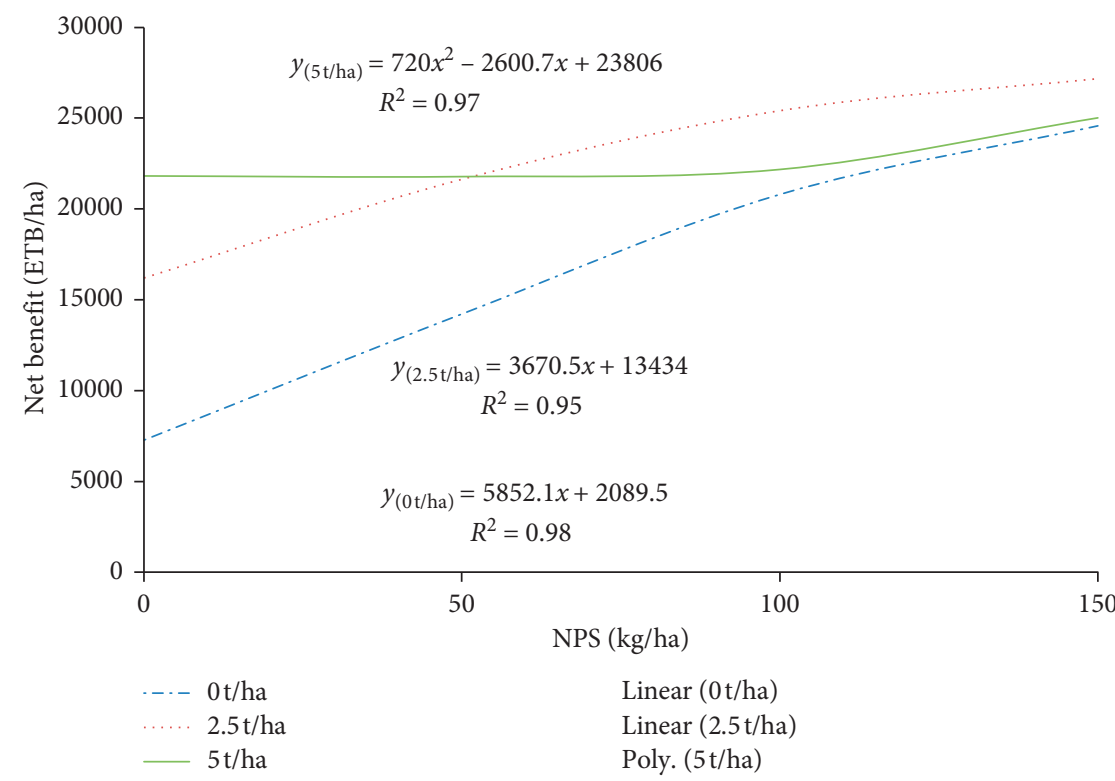

FIGURE 4: Net return of haricot bean as affected by interaction effects of NPS and organic fertilizer. 
TABLE 5: Profitability as affected by NPS and OF fertilizer rates.

\begin{tabular}{|c|c|c|c|c|c|c|c|}
\hline OF $\left(\right.$ tha $\left.^{-1}\right)$ & NPS $\left(\mathrm{kg} \cdot \mathrm{ha}^{-1}\right)$ & GY $\left(\right.$ tha $\left.^{-1}\right)$ & Adj.GY $\left(\right.$ tha $\left.^{-1}\right)$ & GB (ETB) & TVC (ETB) & Net benefit (ETB) & MRR (\%) \\
\hline $\mathbf{0}$ & $\mathbf{0}$ & 1.01 & 0.91 & 7272 & 0.0 & 7272.0 & - \\
\hline $\mathbf{0}$ & 50 & 2.08 & 1.87 & 14976 & 757.5 & 14218.5 & 917.0 \\
\hline $\mathbf{0}$ & 100 & 3.1 & 2.79 & 22320 & 1515.0 & 20805.0 & 869.5 \\
\hline $\mathbf{0}$ & 150 & 3.73 & 3.36 & 26856 & 2272.5 & 24583.5 & 498.8 \\
\hline 2.5 & $\mathbf{0}$ & 2.32 & 2.09 & 16704 & 500.0 & 16204.0 & - \\
\hline 2.5 & 50 & 3.18 & 2.86 & 22896 & 1257.5 & 21638.5 & 717.4 \\
\hline 2.5 & 100 & 3.81 & 3.43 & 27432 & 2015.0 & 25417.0 & 498.8 \\
\hline 2.5 & 150 & 4.16 & 3.74 & 29952 & 2772.5 & 27179.5 & 232.7 \\
\hline 5 & $\mathbf{0}$ & 3.17 & 2.85 & 22824 & 1000.0 & 21824.0 & - \\
\hline 5 & 50 & 3.27 & 2.94 & 23544 & 1757.5 & 21786.5 & $\mathrm{D}$ \\
\hline 5 & 100 & 3.43 & 3.09 & 24696 & 2515.0 & 22181.0 & 52.1 \\
\hline 5 & 150 & 3.93 & 3.54 & 28296 & 3272.5 & 25023.5 & 375.2 \\
\hline
\end{tabular}

Unit cost of NPS $=15.15 \mathrm{ETB} / \mathrm{Kg}$, application cost of organic fertilizer $=20 \mathrm{ETB} / \mathrm{Qt}=200 \mathrm{ETB} /$ ton, MRR $(\%)=$ marginal rate of return, $D=$ dominant $\mathrm{OF}=$ organic fertilizer, $\mathrm{GY}=$ grain yield, $\mathrm{Adj} . \mathrm{GY}=$ adjusted grain yield, $\mathrm{GB}=$ gross benefit, $\mathrm{TVC}=$ total variable cost .

\section{Conclusions}

This study demonstrated that an integrated application of $150 \mathrm{~kg} \cdot \mathrm{NPS} / \mathrm{ha}$ and $2.5 \mathrm{t} \cdot \mathrm{OF} / \mathrm{ha}$ resulted in faster decomposition and the highest growth, yield component, and grain yield over unfertilized crop. The effect on grain yield was triple (312\%) that of unfertilized crop. Additionally, 31\% and $79 \%$ yield increment compared with sole OF application at $2.5 \mathrm{t} / \mathrm{ha}$ and $5 \mathrm{t} / \mathrm{ha}$, respectively, were recorded. Economic analysis has further confirmed the highest net benefit from the combined application of $150 \mathrm{~kg} \cdot \mathrm{NPS} / \mathrm{ha}$ and $2.5 \mathrm{t} \cdot \mathrm{OF} / \mathrm{ha}$. Therefore, under low input cropping systems such as the study area, integrated use of mineral fertilizer with locally available organic nutrient sources are suggested to enhance soil quality and crop productivity. Resource-poor farmers are advised to use sole OF at $5 \mathrm{t} /$ ha as it recorded superior yield and economic advantage over unfertilized to $100 \mathrm{~kg}$.NPS/ha.

\section{Data Availability}

The data used to support the findings of this study are available from the corresponding author upon request.

\section{Conflicts of Interest}

The authors declare that there are no conflicts of interest.

\section{Authors' Contributions}

The authors collected, analyzed, interpreted, and prepared the manuscript.

\section{Acknowledgments}

The authors acknowledge the department of Plant Science of WSU for providing experimental land and support in using the laboratory.

\section{References}

[1] UN (United Nation), World Population Prospects 2019, United Nations, Department of Economics and Social Affairs, Population Division, New York, NY, USA, 2019.
[2] EthioSIS (Ethiopia Soil Information System), "Soil fertility status and fertilizer recommendation Atlas for Tigray regional state, Ethiopia," EthioSIS, Addis Ababa, Ethiopia, 2014.

[3] Ethiopian Soils Information System (EthioSIS), "Soil fertility status and fertilizer recommendation atlas of Amhara national regional state, Ethiopia," EthioSIS, Addis Ababa, Ethiopia, 2016.

[4] K. Jembere, T. Mamo, and K. Kibret, "Characteristics of agricultural landscape features and local soil fertility management practices in Northwestern Amhara, Ethiopia," Journal of Agronomy, vol. 16, no. 4, pp. 180-195, 2017.

[5] F. Laekemariam, K. Kibret, and H. Shiferaw, "Potassium (K) to magnesium $(\mathrm{Mg})$ ratio, its spatial variability and implications to potential Mg-induced $\mathrm{K}$ deficiency in nitisols of southern Ethiopia," Agriculture \& Food Security, vol. 7, p. 13, 2018.

[6] F. Laekemariam and K. Kibret, "Explaining soil fertility heterogeneity in smallholder farms of southern Ethiopia," Applied and Environmental Soil Science, vol. 2020, Article ID 6161059, 16 pages, 2020.

[7] IFPRI (International Food Policy Research Institute), "Fertilizer and soil fertility potential in Ethiopia: constraints and opportunities for enhancing the system," Tech. Report, IFPRI, Washington, DC, USA, 2010.

[8] E. Eyasu, P. F. Okoth, and E. M. A. Smaling, "Explaining bread wheat (Triticum aestivum) yield differences by soil properties and fertilizer rates in the highlands of Ethiopia," Geoderma, vol. 339, pp. 126-133, 2019.

[9] F. Laekemariam, K. Kibert, T. Mamo, H. Gebrekidan, and E. Kidan, "Physiographical characteristics of agricultural land and farmers' soil fertility management practice in Wolaita zone, Southern Ethiopia," Environmental System Research, vol. 5, no. 1, p. 24, 2016.

[10] F. Laekemariam, K. Kibret, T. Mamo, and H. Gebrekidan, "Soil-plant nutrient status and their relations in maizegrowing fields of Wolaita zone, southern Ethiopia," Communications in Soil Science and Plant Analysis, vol. 47, no. 11, pp. 1343-1356, 2016.

[11] B. Iticha and C. Takele, "Digital soil mapping for site-specific management of soils," Geoderma, vol. 351, pp. 85-91, 2019.

[12] R. A. Oliveira, G. Brunetto, A. Loss et al., "Cover crops effects on soil chemical properties and onion yield," Revista Brasileira de Ciência do Solo, vol. 40, Article ID e0150099, 2016.

[13] F. A. M. Rezig, E. A. Elhadi, and A. R. Mubarak, "Impact of organic residues and mineral fertilizer application on soilcrop systems I: yield and nutrients content," Archives of Agronomy and Soil Science, vol. 59, no. 9, pp. 1229-1243, 2013. 
[14] M. L. Cayuela, T. Sinicco, and C. Mondini, "Mineralization dynamics and biochemical properties during initial decomposition of plant and animal residues in soil," Applied Soil Ecology, vol. 41, no. 1, pp. 118-127, 2009.

[15] H. Wassie, "Appraisal of Erythrina bruci as a source for soil nutrition on nitisols of South Ethiopia," International Journal of Agriculture and Biology, vol. 14, no. 3, pp. 371-376, 2012.

[16] F. Laekemaria and G. Gidago, "Growth and yield response of maize (Zea mays L.) to variable rates of compost and inorganic fertilizer integration in Wolaita, Southern Ethiopia," American Journal of Plant Nutrition and Fertilization Technology, vol. 3, no. 2, pp. 43-52, 2013.

[17] H. H. Alhrout, H. K. H. Aldal'in, M. A. Haddad, M. Nabeel, N. M. Bani-Hani, and S. Y. Al-Dalein, "The impact of organic and inorganic fertilizer on yield and yield components of common bean (Phaseolus vulgaris)," Advances in Environmental Biology, vol. 10, no. 9, pp. 8-13, 2016, 2016.

[18] F. A. Rezig, M. E. A. Elhadi, and M. R. Abdalla, "Decomposition and nutrient release pattern of wheat (Triticum aestivum) residues under different treatments in desert field conditions of Sudan," International Journal of Recycling of Organic Waste in Agriculture, vol. 3, no. 3, pp. 1-9, 2014.

[19] I. Sohu, A. W. Gandahi, A. W. Gandahi, G. R. Bhutto, and R. M. S. GandahiSarki, "Growth and yield maximization of chickpea (Cicer arietinum) through integrated nutrient management applied to rice-chickpea cropping system," Sarhad Journal of Agriculture, vol. 31, no. 2, pp. 131-138, 2015.

[20] K. Stewart, Effect of Integrating Organic with Inorganic Fertilizers on Bean Yield on Three Contrasting Soils, Academic Press, San Diego, CA, USA, 2016.

[21] R. Zahida, S. B. Dar, R. Mudasir, and S. Inamullah, "Productivity and quality of French bean (Phaseolus vulgaris L.) as influenced by integrating various sources of nutrients under temperate conditions of Kashmir," International Journal of Food, Agriculture and Veterinary Sciences, vol. 6, no. 1, pp. 15-20, 2016.

[22] B. B. Issoufa, A. Ibrahim, R. C. Abaidoo, and N. EwusiMensah, "Combined use of millet glume-derived compost and mineral fertilizer enhances soil microbial biomass and pearl millet yields in a low-input millet cropping system in Niger," Archives of Agronomy and Soil Science, vol. 65, no. 8, pp. 1107-1119, 2018.

[23] M. J. Kiani, M. K. Abbasi, and N. Rahim, "Use of organic manure with mineral $\mathrm{N}$ fertilizer increases wheat yield at Rawalakot Azad Jammu and Kashmir," Archives of Agronomy and Soil Science, vol. 51, no. 3, pp. 299-309, 2005.

[24] D. Munda and S. Abrham, "Growth, pod yield and qulaity of hot paper (Capsicum annuum L.) as affected by variety and rates of $\mathrm{N}$ fertilizer at Wolaita Sodo, sothen Ethiopia," MSc thesis, Wolaita Sodo University, Ethiopia, 2018.

[25] S. Sahlemedhin and B. Taye, "Procedures for soil and plant analysis," Technical paper 74, National Soil Research Center, Ethiopian Agricultural Research Organization, Addis Abeba, Ethiopia, 2000.

[26] A. Birhanu, "Response of common bean (Phaseolus vulgaris L.) varieties to blended nitrogen, phosphorus and sulfur fertilizer rates at Areka, southern Ethiopia," MSc thesis, Wolaita Sodo University, Ethiopia, 2017.

[27] CIMMYT (International maize \& wheat improvement Center), Economics Training Manual, Mexico City, Mexico, 1998.

[28] SAS, "Statistical Analysis System (Version 9.2.)," SAS Institute Inc., Cary, NC, USA, 2008.
[29] C. A. Palm, "Contribution of agroforestry trees to nutrient requirements of intercropped plants," Agroforestry Systems, vol. 30, no. 1-2, pp. 105-124, 1995.

[30] J. Gindaba, M. Olsson, and F. Itanna, "Nutrient composition and short-term release from Croton macrostachyus Del. and Millettia ferruginea (Hochst.) Baker leaves," Biology and Fertility of Soils, vol. 40, no. 6, pp. 393-397, 2004.

[31] S. Deresa, "Response of common bean (Phaseolus vulgaris L.) varieties to rates of blended NPS fertilizer in Adola district, Southern Ethiopia," African Journal of Plant Science, vol. 12, no. 8, pp. 164-179, 2018.

[32] A. Abebe and Z. Mekonnen, "Common bean (Phaseolus vulgaris L.) varieties response to rates of blended NPKSB fertilizer at Arba Minch, southern Ethiopia," Advances in Crop Science and Technology, vol. 7, p. 429, 2019.

[33] M. Moniruzzaman, M. R. Islam, and J. Hasan, "Effect of N P K $\mathrm{S} \mathrm{Zn}$ and B on yield attributes and yield of French bean in south eastern hilly region of Bangladesh," Journal of Agriculture \& Rural Development, vol. 6, no. 1, pp. 75-82, 2008.

[34] W. Nasim, A. Ahmad, T. Khaliq et al., "Effect of organic and inorganic fertilizer on maize hybrids under agro-environmental conditions of Faisalabad-Pakistan," African Journal of Agricultural Research, vol. 7, no. 17, pp. 2713-2719, 2012.

[35] A. Ahmad and M. Z. Abdin, "Photosynthesis and its related physiological variables in the leaves of Brassica genotypes as influenced by sulphur fertilization," Physiologia Plantarum, vol. 110, no. 1, pp. 144-149, 2000.

[36] G. Abdou, N. Ewusi-Mensah, M. Nouri, F. M. Tetteh, E. Y. Safo, and R. C. Abaidoo, "Nutrient release patterns of compost and its implication on crop yield under Sahelian conditions of Niger," Nutrient Cycling in Agroecosystems, vol. 105, no. 2, pp. 117-128, 2016.

[37] Y. He and R. Li, "Effect of the organo-inorgano-mixed fertilizer application on sugarcane yield and soil enzymatic activity," Sugar Crops China, vol. 4, pp. 36-38, 2004.

[38] S. Saha, V. Prakash, S. Kundu, N. Kumar, and B. L. Mina, "Soil enzymatic activity as affected by long term application of farm yard manure and mineral fertilizer under a rainfed soybeanwheat system in N-W Himalaya," European Journal of Soil Biology, vol. 44, no. 3, pp. 309-315, 2008. 